\title{
Clinical and hematopathological features of adult T-cell leukemia/lymphoma in the area of Amagasaki, Hyogo Prefecture
}

\author{
Hitoshi Ohno ${ }^{a, b}$, Yoshimasa Kamoda ${ }^{a, b}$, Akira Tamekane ${ }^{b}$, Takamasa Hayashi ${ }^{b}$, Kosho Takasu ${ }^{c}$ \\ ${ }^{a}$ Department of Hematology, Tenri Hospital \\ ${ }^{b}$ Department of Hematology, Hyogo Prefectural Amagasaki Hospital \\ ${ }^{c}$ Department of Pathology, Hyogo Prefectural Amagasaki Hospital
}

\begin{abstract}
Here, we report 19 consecutive patients who were diagnosed with adult T-cell leukemia and lymphoma (ATLL) and treated at Hyogo Prefectural Amagasaki Hospital between January 2008 and June 2011. Seven had the acute, 8 had the lymphoma, and 4 had the chronic type of the disease. The age range was 53 to 95 , with a median of 67 . The male to female ratio was 17 to 2. Sixteen of 17 were born in Southwest Japan and had moved to the Hanshin industrial area during their young adulthood. Acute-type patients showed the most aggressive clinical behavior, including a poor performance status, hepatosplenomegaly, pleural fluid/ascites, and high levels of lactate dehydrogenase, soluble interleukin-2 receptor, and serum calcium. Diagnosis of the acute type was readily established in the laboratory on the basis of the characteristic morphology of the circulating neoplastic lymphocytes and activated mature T-cell immunophenotype by flow cytometry, while the histopathological features of lymph nodes overlapped with those of other types of peripheral T-cell lymphoma or Hodgkin lymphoma. Cytogenetic studies revealed a complex karyotype in 8 cases and add(14)(q32) in 2. Five acute and 5 lymphoma-type patients were initially treated with the LSG15 or mLSG15 chemotherapy regimen. Six patients achieved a partial or better response, and 4 lymphoma-type patients showed $>1$ year survival. The marked male predominance most likely reflects the unique demographic configuration of the Amagasaki area. As the aging of patients with ATLL seems to be a nationwide trend within Japan, the development of a treatment strategy that can be tolerated by elderly patients is required.
\end{abstract}

Keywords: adult T-cell leukemia/lymphoma, area of Amagasaki, male predominance, aging, LSG15/mLSG15 regimen

\section{INTRODUCTION}

Adult T-cell leukemia and lymphoma (ATLL), which was first recognized by Takatsuki et al. in $1977,{ }^{1}$ has been established as a tumor of post-thymic activated T-lymphocytes, and the disease is listed in the WHO classification scheme of hematolymphoid neoplasms as a distinct

Received: 2012/5/9 Accepted: 2012/7/17 【Reprint requests】 H. Ohno, $\mathrm{MD}, \mathrm{PhD}$ Department of Hematology, Tenri Hospital 200 Mishima, Tenri, Nara 632-8552, Japan disease entity. ${ }^{2}$ This neoplasm is unique in its pathogenesis, as it is etiologically linked to the human T-cell lymphotropic virus type $1, \mathrm{HTLV}-1 .^{3}$ Another peculiarity of ATLL is that the disease and virus are prevalent in restricted regions within the world, ${ }^{4,5}$ including Southwest Japan, the Caribbean basin, and certain regions of South America and Africa, and in immigrants from these regions living elsewhere.

In Japan, large efforts have been made to estimate the prevalence of HTLV-1 carriers and patients with ATLL in 
each geographical area within the country. ${ }^{5-9}$ The 2009 annual report of the group study for "Survey of HTLV-1 Infection and HTLV-1-Related Diseases in Japan" supported by the Ministry of Health, Labour and Welfare of Japan reported that 1.08 million people currently carry the virus, and 1,146 people develop ATLL per year. ${ }^{10}$ Of HTLV-1 carriers, $45.7 \%$ reside in Kyushu/Okinawa, which has been defined as an endemic area, while $15.9 \%$ reside in the non-endemic Kinki District, ${ }^{7,} 11$ most likely accounted for by the migration of people from Kyushu/ Okinawa to the Osaka/Kobe metropolitan area. ${ }^{9}$ As the incidence of ATLL is expected to parallel the prevalence of HTLV-1 carriers, around 180 patients will newly develop the disease annually in the Kinki District.

Our hospital is located adjacent to the boundary between Hyogo and Osaka Prefectures and included in the Hanshin industrial area, to which a lot of young people moved from Southwest Japan and settled during Japan's period of record economic growth (late 1950s to early 1970s). ${ }^{12}$ Reflecting this particular demographic configuration, we have encountered significant numbers of patients with ATLL and with another HTLV-1-related condition, HTLV-1-associated myelopathy (HAM). ${ }^{13}$ Here, to explore the characteristics of ATLL in the area of Amagasaki, Hyogo Prefecture, we summarize the clinical and hematopathological features of a total of 19 patients with ATLL who were diagnosed and treated at our hospital.

\section{PATIENTS AND METHODS}

This study included 19 consecutive patients who were initially diagnosed with ATLL in Hyogo Prefectural Amagasaki Hospital over 3.5 years between January 2008 and June 2011. The disease of each patient was categorized into the acute, lymphoma, or chronic type according to the Shimoyama diagnostic criteria. ${ }^{14}$ Patients with the smoldering type were not included in this study because of the difficulty in discriminating them from asymptomatic carriers of HTLV-1. ${ }^{15,16}$ Anti-HTLV-1 antibody in the serum was screened by chemiluminescence enzyme immunoassay (CLEIA) and confirmed by HTLV1 -specific western blotting in selected cases.

Patient medical records were reviewed for the clinical data, including birthplace, age, sex, blood counts, white cell differential, and blood chemistry. Mean and/or median values were calculated for continuous numeric data. Imaging studies to identify tumor sites included computed tomography (CT), magnetic resonance imaging, gallium scintigraphy, and positron emission tomography (PET) combined with CT. Endoscopy of the gastrointestinal tract was performed for selected patients.

Diagnostic smear slides from peripheral blood and bone marrow aspirate specimens were air-dried and stained with May-Giemsa. Biopsied specimens were initially examined by hematoxylin-eosin-stained slides, and then subjected to immunohistochemistry using an antibody panel for lymphoid tumors. Images were photographed using an Olympus DP21 Digital Microscope Camera (Olympus Co., Tokyo, Japan) and processed using Adobe Photoshop version 7.0 (Adobe Systems Incorporated, San Jose, CA, USA). Immunophenotyping of leukemia/lymphoma cells by two-color flow cytometry, G-banding cytogenetic analysis, and Southern blot analyses for the T-cell receptor $\beta$-chain gene (TCR- $\beta)$ and HTLV-1 virus genome were outsourced to BML Inc., Tokyo, Japan.

The treatment modality and overall survival in days were obtained by reviewing patient records. Survival estimates were computed by the Kaplan-Meier method.

\section{RESULTS}

\section{Clinical characteristics}

Table 1 summarizes the clinical features and laboratory data at presentation of 19 patients. Seven had the acute type, 8 had the lymphoma type, and 4 had the chronic type of ATLL. Case 6 was included in the acute category, as the disease showed rapid deterioration and thus required immediate treatment, even though the LDH value was below the criterion level (i.e., $>2 \times$ the upper normal limit). Case 14, in which the disease was confined to the stomach with a small percentage of circulating atypical lym- 
Table 1. Clinical and laboratory features of 19 patients with ATLL

\begin{tabular}{|c|c|c|c|c|c|c|c|c|c|c|c|c|c|c|c|}
\hline $\begin{array}{l}\text { Case } \\
\text { no. }\end{array}$ & Category & Age & Sex & PS & $\begin{array}{l}\mathrm{Hp} / \\
\mathrm{Sp}\end{array}$ & $\begin{array}{l}\mathrm{PE} / \\
\mathrm{As}\end{array}$ & $\begin{array}{l}\text { Other } \\
\text { involvements }\end{array}$ & $\begin{array}{r}\text { WBC } \\
\times 10^{3} / \mu 1\end{array}$ & $\begin{array}{l}\text { Lymph } \\
\times 10^{3} / \mu l\end{array}$ & $\begin{array}{l}\mathrm{Hb} \\
\mathrm{g} / \mathrm{dl}\end{array}$ & $\begin{array}{r}\text { PLT } \\
\times 10^{4} / \mu 1\end{array}$ & $\begin{array}{r}\mathrm{LDH} \\
\mathrm{IU} / 1\end{array}$ & $\begin{array}{r}\text { sIL-2R } \\
\mathrm{U} / \mathrm{ml}\end{array}$ & $\begin{array}{r}\mathrm{Ca} \\
\mathrm{mg} / \mathrm{dl}\end{array}$ & $\begin{array}{r}\mathrm{CRP} \\
\mathrm{mg} / \mathrm{dl}\end{array}$ \\
\hline 1 & Acute & 65 & M & 2 & + & - & - & 50 & 44.5 & 14.8 & 6.2 & 2,892 & 124,159 & 12.6 & 0.80 \\
\hline 2 & Acute & 54 & M & 3 & - & - & - & 15.5 & 10.2 & 14.6 & 8.9 & 610 & 27,586 & 18.8 & 2.60 \\
\hline 3 & Acute & 95 & $\mathrm{~F}$ & 4 & - & - & Sk & 68.5 & 60.3 & 12.8 & 5.6 & 1,150 & NT & 13.3 & 1.10 \\
\hline 4 & Acute & 75 & M & 4 & + & + & - & 13 & 4.8 & 10.9 & 6.2 & 1,889 & 178,871 & 12.3 & 6.50 \\
\hline 5 & Acute & 62 & $\mathrm{M}$ & 2 & + & - & - & 44.6 & 31 & 14.1 & 16.2 & 1,375 & 41,329 & 12.1 & 1.39 \\
\hline 6 & Acute & 53 & M & 2 & + & - & - & 22.1 & 15.5 & 10.3 & 20.8 & 442 & 18,865 & 8.7 & 0.09 \\
\hline \multirow[t]{2}{*}{7} & Acute & 67 & M & 3 & + & + & - & 34.9 & 8.9 & 14.8 & 19 & 1,139 & 112,288 & 11.1 & 0.37 \\
\hline & & (65) & & & & & & (34.9) & (15.5) & (14.1) & (8.9) & $(1,150)$ & $(76,808.5)$ & $(12.3)$ & (1.10) \\
\hline 8 & Lymphoma & 63 & $\mathrm{M}$ & 1 & - & - & - & 5.7 & 1.7 & 12.6 & 20 & 253 & 3,237 & 9.0 & 0.40 \\
\hline 9 & Lymphoma & 57 & M & 1 & - & - & - & 10 & 1.8 & 12.8 & 9.9 & 917 & 9,169 & 9.6 & 0.50 \\
\hline 10 & Lymphoma & 71 & M & 1 & - & - & St, B, Pr, CSF & 4.9 & 0.2 & 11.3 & 29.6 & 662 & 156,695 & 8.3 & 2.54 \\
\hline 11 & Lymphoma & 76 & M & 1 & - & - & - & 9.1 & 1.4 & 12.2 & 20.4 & 199 & 2,626 & 8.2 & 2.87 \\
\hline 12 & Lymphoma & 61 & M & 1 & - & - & $\mathrm{B}, \mathrm{Sk}, \mathrm{Pr}, \mathrm{Pl}$ & 12.9 & 1 & 12.5 & 46.8 & 260 & 6,556 & 9.3 & 8.14 \\
\hline 13 & Lymphoma & 73 & M & 3 & - & - & - & 18.6 & 1.3 & 14.4 & 29.1 & 731 & 4,045 & 10.3 & 18.07 \\
\hline 14 & Lymphoma & 69 & $\mathrm{~F}$ & 1 & - & - & St & 4.8 & 0.9 & 12.4 & 32.7 & 215 & 4,483 & 9.3 & 0.62 \\
\hline \multirow[t]{2}{*}{15} & Lymphoma & 71 & M & 4 & - & - & - & 6.1 & 0.7 & 12.1 & 34.1 & 2,039 & 61,105 & 9.3 & 2.66 \\
\hline & & $(70)$ & & & & & & $(7.6)$ & $(1.1)$ & $(12.45)$ & $(29.35)$ & $(461)$ & $(5,519.5)$ & $(9.3)$ & $(2.60)$ \\
\hline 16 & Chronic & 84 & M & 1 & - & $(+)^{*}$ & - & 11.7 & 5.3 & 12.6 & 21.9 & 192 & 4,952 & 8.9 & 0.10 \\
\hline 17 & Chronic & 78 & M & 2 & - & - & - & 13 & 5.9 & 13.2 & 29.1 & 219 & 2,370 & 8.8 & 1.23 \\
\hline 18 & Chronic & 60 & M & 1 & - & - & Sk & 15.2 & 6.5 & 14.2 & 28.8 & 212 & 4,209 & 9.1 & 0.35 \\
\hline 19 & Chronic & 66 & M & 1 & - & - & Sk & 14.3 & 6.5 & 13.9 & 15.4 & 405 & 20,779 & 10.0 & 0.21 \\
\hline & & (72) & & & & & & (13.65) & $(6.2)$ & $(13.55)$ & $(25.35)$ & $(215.5)$ & $(4,580.5)$ & $(9.0)$ & $(0.28)$ \\
\hline
\end{tabular}

Abbreviations: PS, performance status; Hp/Sp, hepatosplenomegaly; PE/As, pleural effusions/ascites; WBC, white blood cells; Lymph, lymphocytes; Hb, hemoglobin; PLT, platelets; LDH, lactate dehydrogenase; sIL-2R, soluble interleukin-2 receptor; Ca, serum calcium; CRP, C-reactive protein; Sk, skin; St, stomach, B, bone; Pr, prostate; CSF, cerebrospinal fluids; Pl, pleura; NT, not tested.

Median values of each category are indicated in parenthesis. *Pleural fluids appeared with disease progression.

phocytes, was included in the lymphoma category. ${ }^{16}$ All 19 patients were positive for anti-HTLV-1 antibody by CLEIA, and 9 patients studied were positive for the antibody by western blotting. Of 17 patients whose birthplace was recorded, 14 patients were born in Kyushu and on neighboring islands, 1 in Okinawa, and 1 in Shikoku, and they moved to the Hanshin area during their young adulthood. The remaining 1 patient was born in Hyogo Prefecture.

The age range was 53 to 95 , with a mean of 68.4 and a median of 67 . The male to female ratio was 17 to 2 . The majority of the patients initially presented with leukemic manifestation and/or generalized lymphadenopathy. Two had a gastric tumor, which had been misdiagnosed as gas- tric cancer (cases 10 and 14). Involvements of the bone and prostate were identified by PET/CT imaging study (cases 10 and 12; Figure 1). In one patient, HAM preceded the development of ATLL (case 2). Among the 3 disease categories, the acute type showed the most aggressive clinical behavior, including a poor performance status, association of hepatosplenomegaly, and pleural fluid/ascites. High levels of lactate dehydrogenase, soluble interleukin-2 receptor, and serum calcium, and low platelet counts were prominent in the acute-type category.

Morphology of leukemic cells and histopathology of lymph nodes and other tissues

Leukemic cells of ATLL in the peripheral blood and bone marrow are characterized by polylobulated nuclei, 


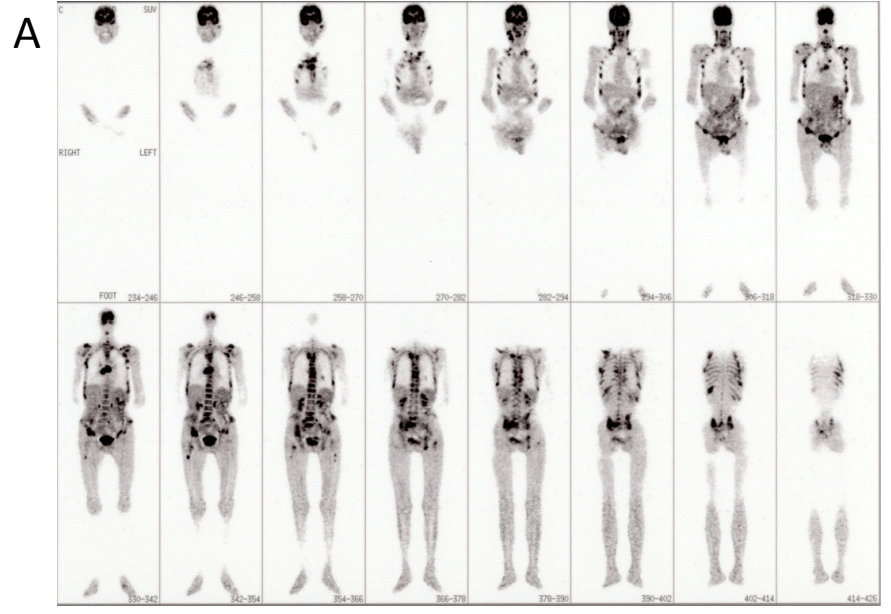

designated "flower cells" (Figure 2A, left). ${ }^{1,2}$ However, circulating lymphocytes with this characteristic morphology were infrequent, and nuclear irregularity was less prominent in the majority of leukemic cells. Nevertheless, the cells were readily recognized by their chromatin-rich nuclei and basophilic cytoplasm (Figure 2A, right). Occasionally, the cells showed a blastic cell morphology with dispersed nuclear chromatin and nucleoli (Figure 2B), or a bi-nucleated Reed-Sternberg (RS) celllike appearance (Figure 2C).

Lymph node biopsies were obtained from 9 patients. Histopathological examination of the biopsies revealed pleomorphic cellular infiltrates composed of lymphoid cells of various sizes with various nuclear shapes as well as multi-nucleated large cells (Figure $3 \mathrm{~A}$ to $\mathrm{C}$ ). In 2 cases, there were RS-like cells expressing the CD30 and CD15 antigens; indeed, the histological features resembled Hodgkin lymphoma (Figure 3D to F) or angioimmunoblastic T-cell lymphoma. In one case, the lymph node showed diffuse infiltrates of CD30-positive large anaplastic cells (Figure $3 \mathrm{G}$ to I).

Biopsies of gastric tumors were obtained in 2 cases. Both cases showed mucosal infiltrates of neoplastic Tcells with features of epitheliotropic proliferation (Figure $3 \mathrm{~J}$ to $\mathrm{L}$ ). Skin histopathology was available in two chronic-type patients, showing dermal lymphoid infiltrates associated with epidermotropism (not shown).

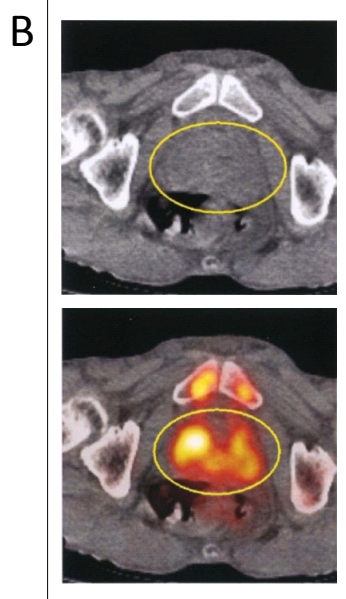

Figure 1. PET/CT images of case 12

$A$, Coronal sections of the whole body, showing the accumulation of ${ }^{18} \mathrm{~F}$-fluorodeoxyglucose (FDG) in the cervical, supraclavicular, and mediastinal lymph nodes as well as widespread bone involvement in the spine, pelvis, ribs, and femurs. $B$, Transverse sections showing the accumulation of FDG within the prostate (circle) and pubic bone.

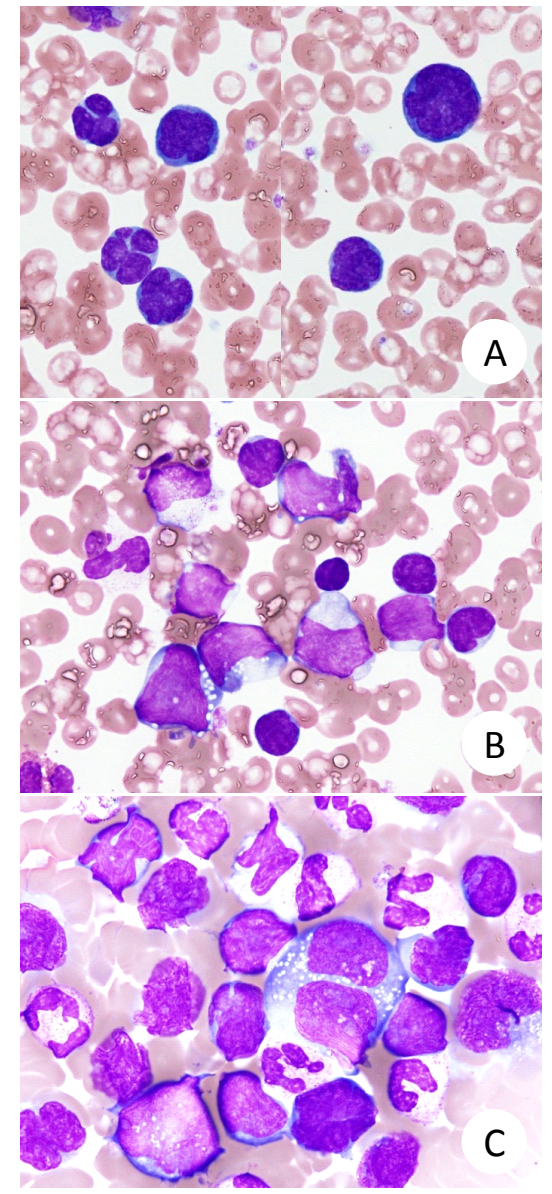

Figure 2. Appearance of May-Giemsa-stained leukemic cells $(\times 100$, objective)

$A$ (case 7), The cells were characterized by condensed nuclear chromatin and basophilic cytoplasm, while the degree of nuclear irregularity and cell size varied considerably among the cells. $B$ (case 5), The cells were composed of small, mature lymphoid cells and large blasts. $C$ (case 15), The cells were large blasts, including "mirror-image" bi-nucleated cells. There were a lot of nuclear shadows. 


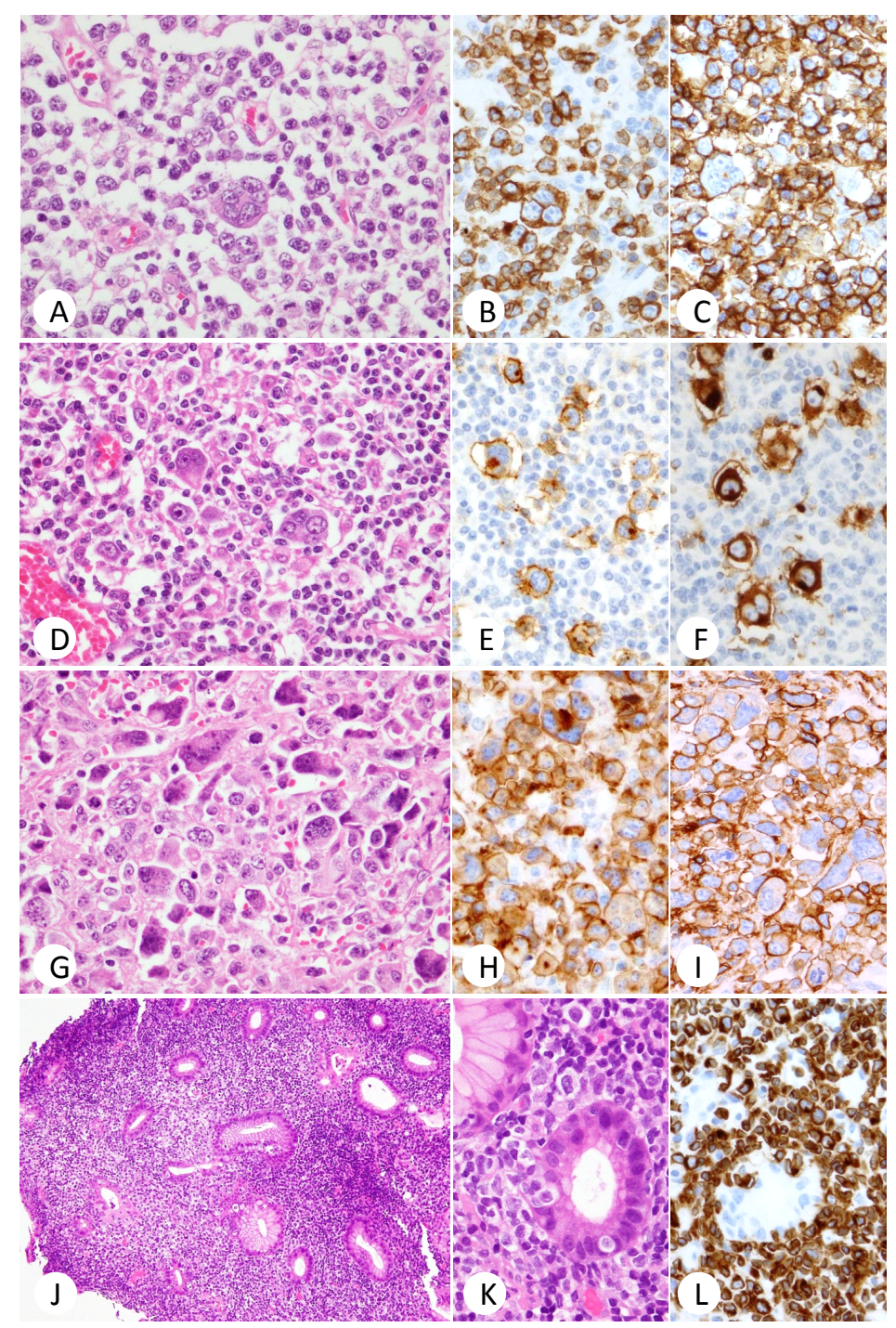

\section{Figure 3. Histopathology of biopsies}

$A$ to $C$ (case 13), The lymph node was composed of pleomorphic, medium-sized to large cells and multinucleated cells $(A, \mathrm{H} \& \mathrm{E}$ staining, $\times 40$ objective), which expressed cytoplasmic CD3 (cCD3) $(B, \times 40$ objective) and CD45RO $(C, \times 40$ objective). $D$ to $F$ (case 11 ), The lymph node contained Reed-Sternberg-like large cells $(D, \times 40$ objective), which expressed CD30 distributed on the cell surface and in the Golgi area $(E, \times 40$ objective), and CD15 both on the cell surface and in the cytoplasm $(F, \times 40$ objective $)$. As the cells were positive for CD20 (not shown), they appeared to be non-neoplastic B-cells infected with EpsteinBarr virus. G to I (case 15), The lymph node was filled with large anaplastic cells $(G, \times 40$ objective), positive for $\mathrm{CD} 30(H, \times 40$ objective $)$ and CD45RO ( $I, \times 40$ objective). ALK was negative (not shown). According to the classification by Ohshima, ${ }^{20,23}$ each case corresponds to the pleomorphic (case 13), Hodgkin-like (case 11), and anaplastic large cell (case 15) types, respectively. J to L (case 10), Biopsy of the stomach showed diffuse mucosal infiltrates of lymphoid cells $(J, \times 10$ objective $)$, and cCD3positive atypical cells penetrating the gastric gland ( $K$ and $L, \times 40$ objective).

\section{Immunophenotype of ATLL neoplastic cells by flow cytometry}

Leukemia/lymphoma cells, obtained from peripheral blood, bone marrow, lymph node, pleural fluid, or cerebrospinal fluid, were subjected to immunophenotypic analysis by flow cytometry. As summarized in Table 2, the cells from 15 cases expressed the T-cell antigens CD2, CD3, and CD5; however, the expression of these antigens was sometimes diminished or absent. Expression of CD7 was variable. CD4 was positive in all cases except one, while no case expressed CD8. T-cell activation markers such as CD25 and HLA-DR were variably expressed among cases, and a single case expressed CD56. The immunophenotype in the tissues determined by immuno- histochemistry was comparable with those determined by flow cytometry.

\section{Cytogenetic abnormalities and molecular studies}

Of 12 patients in whom cytogenetic data were available, 8 had clonal abnormalities. Modal chromosome numbers ranged from 45 to 94 . Numerical abnormalities observed in 2 or more cases were $+\mathrm{X},-\mathrm{Y},+3,+7,+9,-10,+11,-13$, $-14,+15,+16,+17,+18,-18,+20,-20$, and +22 , and structural abnormalities in 2 or more cases were add(1)(p11), $\operatorname{add}(2)(q 21), \operatorname{add}(2)(q 33), \operatorname{add}(3)(p 13), \operatorname{add}(3)(q 21)$, $\operatorname{add}(4)(\mathrm{q} 21), \operatorname{add}(5)(\mathrm{q} 31), \operatorname{add}(7)(\mathrm{p} 22), \operatorname{add}(7)(\mathrm{p} 11.2)$, $\operatorname{add}(11)(q 13)$, and $\operatorname{add}(14)(q 32)$ (Figure 4). Additional chromosomal material of each derivative chromosome could not be determined by G-banding analysis. 
Table 2. Expression of cell surface antigens determined by flow cytometry

\begin{tabular}{|c|c|c|c|c|c|c|c|c|c|c|}
\hline Case no. & Materials $^{*}$ & $\mathrm{CD} 2$ & $\mathrm{CD} 3$ & $\mathrm{CD} 4$ & CD5 & $\mathrm{CD} 7$ & $\mathrm{CD} 8$ & $\mathrm{CD} 25$ & CD56 & HLA-DR \\
\hline 1 & PB & + & + & + & - & - & - & $+\mathrm{w}$ & - & - \\
\hline 2 & PB & + & + & + & + & - & - & + & - & - \\
\hline 4 & LN & + & + & + & + & $+\mathrm{w}$ & - & + & - & $+\mathrm{w}$ \\
\hline 5 & $\mathrm{BM}$ & + & + & + & + & - & - & $+\mathrm{w}$ & - & + \\
\hline 6 & $\mathrm{BM}$ & + & + & + & + & $+\mathrm{w}$ & - & NT & - & $+\mathrm{w}$ \\
\hline 7 & $\mathrm{BM}$ & - & - & + & + & - & - & NT & + & - \\
\hline 9 & $\mathrm{LN}$ & + & - & + & + & + & - & + & - & - \\
\hline 10 & $\mathrm{CSF}$ & + & $+\mathrm{w}$ & + & + & - & - & + & - & NT \\
\hline 12 & $\mathrm{LN}$ & + & + & + & + & + & - & - & - & $+\mathrm{w}$ \\
\hline 13 & $\mathrm{LN}$ & + & + & - & + & - & - & - & - & - \\
\hline 15 & $\mathrm{BM}$ & + & - & + & - & - & - & + & - & + \\
\hline 16 & $\mathrm{PE}$ & + & - & + & - & - & - & NT & - & + \\
\hline 17 & $\mathrm{BM}$ & + & + & + & + & $+\mathrm{w}$ & - & $+\mathrm{w}$ & - & $+\mathrm{w}$ \\
\hline 18 & PB & + & + & + & + & $+w$ & - & + & - & NT \\
\hline 19 & $\mathrm{BM}$ & + & + & + & + & - & - & NT & - & - \\
\hline
\end{tabular}

,$+ \geq 50 \% ;+$ w (weak), $\geq 10 \%,<50 \% ;-,<10 \%$; NT, not tested.

*LN, lymph node; BM, bone marrow; PB, peripheral blood; CSF, cerebrospinal fluid; PE, pleural effusion.

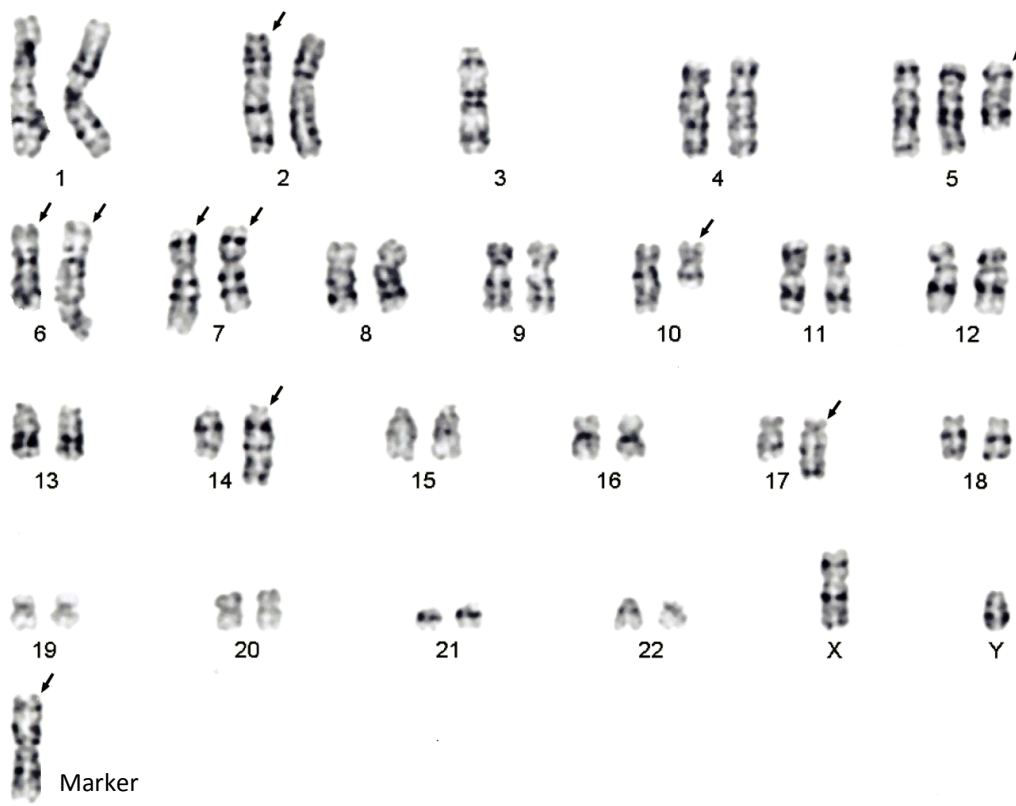

Figure 4. G-banded karyotype of case 5 obtained from the bone marrow

Arrows indicate rearranged chromosomes. The karyotype was: 47,XY, add(2)(q21),-3, $+\operatorname{add}(5)(\mathrm{q} 31), \operatorname{add}(6)(\mathrm{q} 15), \operatorname{add}(6)(\mathrm{q} 25)$, $\operatorname{add}(7)(\mathrm{p} 22), \operatorname{der}(7) \operatorname{add}(7)(\mathrm{p} 22) \operatorname{add}(7)(\mathrm{q} 32)$, $\operatorname{add}(10)(\mathrm{q} 11.2), \operatorname{add}(14)(\mathrm{q} 32), \operatorname{add}(17)(\mathrm{q} 25)$, + mar. Additional chromosomal materials of $\operatorname{add}(14)(q 32)$ were not determined by Gbanding.

The TCR- $\beta$ gene was rearranged as determined by Southern blot in 5 of 8 cases studied. Three cases were studied for the HTLV-1 genome by Southern blot, showing the clonal integration of provirus in the tumor cells.

\section{Treatment and outcome}

Five acute- and 5 lymphoma-type patients were initially treated with the LSG15 or mLSG15 chemotherapy regimen, ${ }^{17,18}$ consisting of 6 or 7 cycles of VCAP (vincristine, cyclophosphamide, doxorubicin, and prednisone), AMP (doxorubicin, ranimustine, and prednisone), VECP (vindesine, etoposide, carboplatin, and prednisone), and intrathecal methotrexate and prednisone or methotrexate, 
cytarabine, and prednisone, with the support of granulocyte colony-stimulating factor. Six of the 10 patients achieved a partial response (PR) or better, ${ }^{19}$ and 4 lymphoma-type patients showed $>1$ year survival. Two patients underwent allogeneic stem-cell transplantation during remission in other institutions (cases 5 and 9). Other initial treatments included chemotherapy with CHOP (cyclophosphamide, doxorubicin, vincristine, and prednisone) for 1 patient, ABVD (doxorubicin, bleomycin, vinblastine, and prednisone) for 1 , oral etoposide for 4 , and best supportive care for 2. As of the end of March 2012, with a median follow-up of 281 days, 5 patients were alive.

Figure 5A shows the Kaplan-Meier survival curves of all 19 presented patients and 10 patients treated with LSG15/mLSG15; the median overall survival time of the 19 patients was 305 days. Among the three disease categories, the acute type showed the worst survival, and the difference with the lymphoma type was significant (logrank test, $P=0.029$ ) (Figure $5 \mathrm{~B}$ ).

\section{DISCUSSION}

This study revealed the clinical characteristics of ATLL in the area of Amagasaki, Hyogo Prefecture, which has a unique demographic structure resulting from the population movement associated with Japan's economic growth after World War II. ${ }^{12}$ The marked male predominance, as compared with the nationwide male/female ratio of $1.16,{ }^{10}$ suggests that men, during their young adulthood, had moved from Kyushu/Okinawa District and settled in this area in response to the demand for labor. As this population is expected to reach the age of development of ATLL at around the same time, male predominance of this disease in this particular area will continue in the future.

Another finding of this study was that the mean and median ages of the patients were 68.4 and 67, respectively. In earlier studies performed during the 1980 s to 1990s by the Lymphoma Study Group, the mean age of patients with ATLL rose steadily from 58.3 (1988 to 1989) to 61.1 (1996 to 1997). ${ }^{6}$ On the other hand, the 2009
A

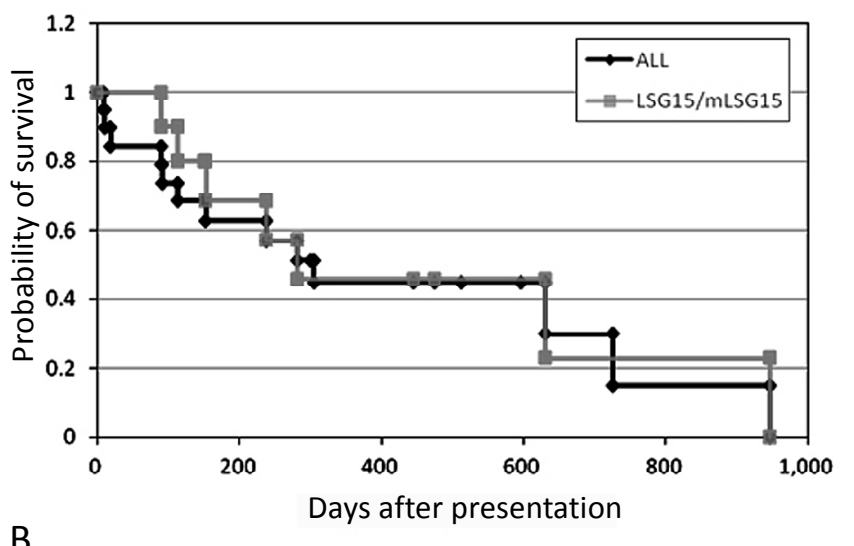

B

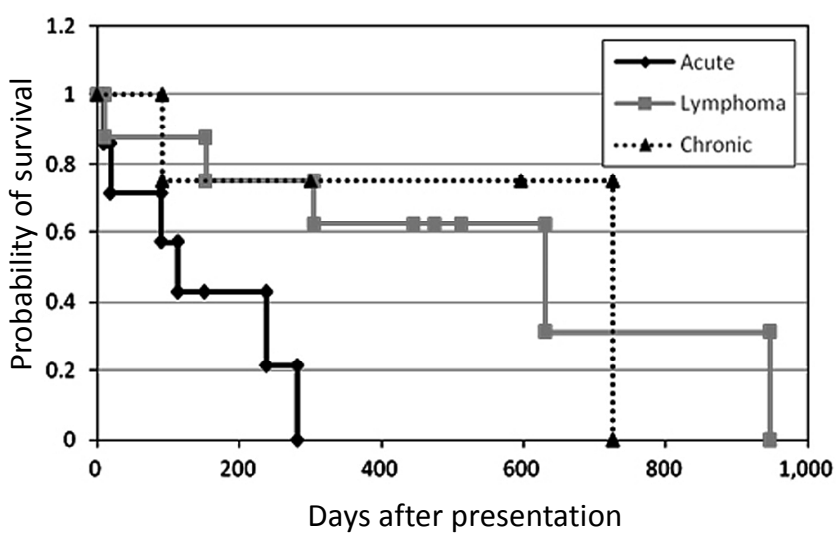

Figure 5. Kaplan-Meier survival curves

$A$, Survival of all 19 patients with ATLL and 10 patients treated with LSG15/mLSG15 chemotherapy. Four patients who were treated with LSG15/mLSG15 and survived $>1$ year had the lymphoma-type disease. $B$, Survival of acute-type $(\mathrm{n}=7)$, lymphoma-type $(n=8)$, and chronic-type $(n=4)$ patients. The median duration of observation was 114 days for acute, 460.5 days for lymphoma, and 448 days for chronic-type patients. The person-year mortality rate was 0.779 (95\% confidence interval [CI], 0.453-1.342) for all, and 2.432 (95\% CI, 1.093$5.414)$ for the acute, $0.525(95 \% \mathrm{CI}, 0.218-1.261)$ for the lymphoma, and 0.426 (95\% CI, $0.107-1.705)$ for the chronic disease category.

annual report showed that the median age rose further to 67 and the age distribution peaked between 66 and 75. ${ }^{10}$ Accordingly, the peak of the age distribution of HTLV-1 carriers shifted from the $50 \mathrm{~s}$ in 1988 to the $60 \mathrm{~s}-70 \mathrm{~s}$ in 2007. ${ }^{11}$ Thus, it seems that the aging of patients with ATLL is not restricted to the area of Amagasaki, but is a nationwide trend within Japan. 
Our current study showed that the acute and lymphoma types of ATLL occurred at comparable rates. In the initial study by Shimoyama and in the total of 3,761 patients registered by the Lymphoma Study Group between 1988 and 1997, the acute type accounted for 55.7 and $60.2 \%$ of the patients studied, while the lymphoma type accounted for 19.1 and $23.7 \%$, respectively. ${ }^{6}, 14$ The 2009 annual report, on the other hand, showed that the percentages of each category were: acute, 46.7\%; lymphoma, 34.8\%; chronic, $8.2 \%$; and smoldering, $10.3 \%$, indicating an increased occurrence of the lymphoma type. ${ }^{10}$ The report suggests that this change in the acute/lymphoma ratio could be related to the aging of the patients, ${ }^{10}$ indeed, in our series, the median age of patients with the lymphoma type was higher than that of those with the acute type.

Diagnosis of the acute type of ATLL can be readily established in the laboratory on the basis of the characteristic morphology of the circulating neoplastic lymphocytes and activated mature T-cell immunophenotype. In contrast, diagnosis of the pure lymphoma type is often problematic as the histological features of ATLL overlap with those of other types of peripheral T-cell lymphoma or Hodgkin lymphoma. Indeed, case 11 was initially treated with ABVD combination chemotherapy under the diagnosis of mixed cellularity Hodgkin lymphoma. ${ }^{2,20}$ In principle, lymphoma tissues should be subjected to molecular studies for the rearrangement of TCR genes and the HTLV-1 virus genome to confirm monoclonal expansion of HTLV-1-infected T-cells; however, these studies are not approved in clinical practice. Thus, we are not able to exclude the possibility that our current series included HTLV-1-unrelated peripheral T-cell lymphoma/ Hodgkin lymphoma. Of course, in any type of ATLL, investigation of the HTLV-I serology and information on the birthplace are essential for the diagnosis of the disease.

Cytogenetic analysis of ATLL often shows a complex karyotype in each case and variable abnormalities among the cases, ${ }^{21}$ presumably reflecting diverse secondary genetic changes related to the disease progression. Thus, distinct cytogenetic abnormality primarily involved in the development of ATLL has not yet been identified. ${ }^{2} \mathrm{Nev}-$ ertheless, by analogy with the translocations in mature Bcell tumors involving the $14 \mathrm{q} 32$ /immunoglobulin heavy chain gene locus, translocation/inversion involving the $14 \mathrm{q} 11$ chromosomal band, where the TCR- $\alpha$ and $-\delta$ chain genes are located, has been highlighted. ${ }^{22}$ The TCL1 gene was isolated on $14 \mathrm{q} 32.1$ by cloning $\mathrm{t}(14 ; 14)(\mathrm{q} 11 ; \mathrm{q} 32.1)$ or inv(14)(q11;q32.1), and the gene was shown to be activated in mature T-cell tumors carrying the rearrangement of this gene locus. ${ }^{22}$ It is therefore possible that $\operatorname{add}(14)(q 32)$ found in 2 cases in our series affected the TCL1 and/or franking genes.

Treatment of ATLL has been a challenge for physicians in the field of hematology/oncology. Patients usually do not respond or have only transient responses to chemotherapy regimens that are effective in aggressive lymphomas of the B-cell type. The LSG15 regimen was initially applied to 96 previously untreated ATLL patients in a phase 2 fashion, resulting in a rate of complete response (CR) of $35.5 \%$ and median survival of 13 months. ${ }^{18}$ The CR rates of each category were $19.6 \%$ for the acute, $66.7 \%$ for the lymphoma, and $40 \%$ for the chronic type; accordingly, patients with the lymphoma type survived for longer than those with the acute type. ${ }^{18}$ The Lymphoma Study Group subsequently performed a phase 3 study, in which the mLSG15 regimen was compared with 8 cycles of biweekly CHOP. ${ }^{17}$ The results showed that mLSG15 was superior to biweekly CHOP in terms of the CR rate and 3 -year overall survival. ${ }^{17}$ In our series, of $6 \geq \mathrm{PR}$ patients with LSG15/mLSG15, 4 with the lymphoma type showed $>1$ year survival (Figure 5A), in accordance with the fact that lymphoma-type patients benefit from these intensive chemotherapy regimens. ${ }^{16}$ However, as the median ages of patients in these two studies by the Lymphoma Study Group were 54.5 and 56, ${ }^{17,18}$ their results are not necessarily applicable to clinical practice, in which, as in our series, elderly patients are included. Indeed, we often encountered prolonged grade 4 neutropenia and thrombocytopenia after AMP and VECP courses, making it difficult 
to complete the treatment as scheduled, and even leading to a reduction of the dosage of each chemotherapeutic agent. As the aging of patients with ATLL is a nationwide trend, the development of a treatment strategy that can be tolerated by elderly patients is required.

\section{REFERENCES}

1. Uchiyama T, Yodoi J, Sagawa K, et al. Adult T-cell leukemia: clinical and hematologic features of 16 cases. Blood 1977;50:481-492.

2. Oshima K, Jaffe ES, Kikuchi M. Adult T-cell leukaemia/ lymphoma. In: Swerdlow SH, Campo E, Harris NL, et al., eds. WHO Classification of Tumours of Haematopoietic and Lymphoid Tissues. Lyon: IARC;2008:281-284.

3. Matsuoka M, Jeang KT. Human T-cell leukaemia virus type 1 (HTLV-1) infectivity and cellular transformation. Nat Rev Cancer 2007;7:270-280.

4. Proietti FA, Carneiro-Proietti AB, Catalan-Soares BC, et al. Global epidemiology of HTLV-I infection and associated diseases. Oncogene 2005;24:6058-6068.

5. Watanabe T. Current status of HTLV-1 infection. Int J Hematol 2011;94:430-434.

6. Hirose K, Tajima K. T- and B-Cell Malignancy Study Group: The nineth nation-wide study of adult T-cell leukemia/lymphoma (ATL) in Japan. Gan no Rinsho 2001;4: 341-357.

7. Satake M, Yamaguchi K, Tadokoro K. Current prevalence of HTLV-1 in Japan as determined by screening of blood donors. J Med Virol 2012;84:327-335.

8. Uchimaru K, Nakamura Y, Tojo A, et al. Factors predisposing to HTLV-1 infection in residents of the greater Tokyo area. Int J Hematol 2008;88:565-570.

9. Tajima K. The 4th nation-wide study of adult T-cell leukemia/lymphoma (ATL) in Japan: estimates of risk of ATL and its geographical and clinical features. The T- and Bcell Malignancy Study Group. Int J Cancer 1990;45:237243.

10. Yamaguchi K. [2009 Annual Report: Survey of HTLV-1 Infection and HTLV-1 Related Diseases in Japan, Research Project for Novel Influenza, Emerging and Re-emerging Infectious Disease (supported by the Ministry of Health, Labour and Welfare of Japan)]; 2010.

11. Yamaguchi K. [2008 Annual Report: Survey of HTLV-1 infection and HTLV-1-Related Diseases in Japan, Research Project for Emerging and Re-emerging Infectious Disease (supported by the Ministry of Health, Labour and Welfare of Japan)]; 2009.

12. Yamaguchi S. [Column: A City of People Who Left Their Home Towns, Illustrative History of Amagasaki (Web Edition)]. Available at:http://www.archives.city.amagasaki. hyogo.jp/chronicles/visual/05 gendai/gendai2-c4.html. Accessed April 21, 2012.

13. Nagai M, Osame M. Human T-cell lymphotropic virus type I and neurological diseases. J Neurovirol. 2003;9:228-235.

14. Shimoyama M. Diagnostic criteria and classification of clinical subtypes of adult T-cell leukaemia-lymphoma. A report from the Lymphoma Study Group (1984-87). Br J Haematol 1991;79:428-437.

15. Uchimaru K. [Current problems on the management of HTLV-1 asymptomatic carriers and ATL patients]. Rinsho Ketsueki 2011;52:1432-1438.

16. Bazarbachi A, Suarez F, Fields P, et al. How I treat adult Tcell leukemia/lymphoma. Blood. 2011;118:1736-1745.

17. Tsukasaki K, Utsunomiya A, Fukuda H, et al. VCAP-AMPVECP compared with biweekly CHOP for adult T-cell leukemia-lymphoma: Japan Clinical Oncology Group Study JCOG9801. J Clin Oncol 2007;25:5458-5464.

18. Yamada Y, Tomonaga M, Fukuda H, et al. A new G-CSFsupported combination chemotherapy, LSG15, for adult T-cell leukaemia-lymphoma: Japan Clinical Oncology Group Study 9303. Br J Haematol 2001;113:375-382.

19. Tsukasaki K, Hermine O, Bazarbachi A, et al. Definition, prognostic factors, treatment, and response criteria of adult T-cell leukemia-lymphoma: a proposal from an international consensus meeting. J Clin Oncol 2009;27:453-459.

20. Ohshima K. Pathological features of diseases associated with human T-cell leukemia virus type I. Cancer Sci 2007;98:772-778.

21. Correlation of chromosome abnormalities with histologic and immunologic characteristics in non-Hodgkin's lymphoma and adult $\mathrm{T}$ cell leukemia-lymphoma. Fifth International Workshop on Chromosomes in Leukemia-Lymphoma. Blood 1987;70:1554-1564.

22. Pekarsky Y, Hallas C, Croce CM. Molecular basis of mature T-cell leukemia. JAMA 2001;286:2308-2314.

23. Takeshita M, Ohshima K, Akamatsu M, et al. CD30-positive anaplastic large cell lymphoma in a human T-cell lymphotropic virus-I endemic area. Hum Pathol 1995; 26:614-619. 


\title{
兵庫県立尼崎病院で診療した成人 T 細胞白血病・リンパ腫 19 症例の検討
}

\author{
大野仁嗣 $a, b$, , 鴨田吉正 ${ }^{a, b}$, 為金 現 ${ }^{b}$ 林 孝昌 ${ }^{b}$, 鷹巣晃昌 $c$ \\ $a$ 天理よろづ相談所病院 血液内科 \\ $b$ 兵庫県立尼崎病院 血液内科 \\ $c$ 兵庫県立尼崎病院 病理診断科
}

成人 T 細胞白血病・リンパ腫 (adult T-cell leukemia/lymphoma; ATLL) は西南日本で頻度が高いが，兵庫県立 尼崎病院では地域的な特性のため, 多くのATLL患者を診療している. 2008 年 1 月から 2011 年 6 月までの 3.5 年間に同院で診療した ATLL 患者 19 症例を検討した.

結果:下山分類では, 急性型 7 例, リンパ腫型 8 例, 慢性型 4 例であった。年齢は 53-95 歳（中央值 67 歳），男 女比 17/2, 17 例中 16 例が九州・沖縄・四国地方の出身で, 青年期に阪神地域に転入した．急性型が最も劇 症で, performance status のグレードが高く，肝脾腫や胸・腹水を伴うことが多く，LDH，可溶性 IL-2 レセプ ター, 血清カルシウムが高値を示した，末梢血中の腫瘍細胞の特徵的な形態と，フローサイトメトリーによ る活性化末梢性 $\mathrm{T}$ 細胞の免疫形質の検出によって, 急性型の診断は容易であるが，リンパ節の病理形態は他 の末梢性 T細胞リンパ腫やホジキンリンパ腫の病理形態とオーバーラップした. 染色体分析では8例にクロー ン性染色体異常, 2 例に add(14)(q32)を認めた. 急性型 5 例, リンパ腫型 5 例が LSG15/mLSG15 プロトコール による化学療法を受けた。 6 例が部分寛解または完全寛解に到達し, リンパ腫型 4 例が 1 年以上生存した. 考案: 今回の検討で認められた著しい男性優位は, 尼崎地域の人口構成の特性を反映していると考えられる. ATLL 患者の高齢化は全国的な傾向であるので, 高齢者にも実施可能な治療戦略を確立する必要がある.

キーワード: 成人 $\mathrm{T}$ 細胞白血病・リンパ腫, 尼崎地域, 男性優位, 高齢化, LSG15/mLSG15 プロトコール 